\title{
Demographic Factors and Risk Indicators of Stroke: Comparison Between Inhabitants of Fortaleza Municipal District and the National Profile ${ }^{1}$
}

\author{
Tahissa Frota Cavalcante ${ }^{2}$ \\ Rafaella Pessoa Moreira ${ }^{3}$ \\ Thelma Leite de Araujo ${ }^{4}$ \\ Marcos Venicios de Oliveira Lopes ${ }^{5}$
}

The aim of this study was to compare the demographic factors and the risk indicators for the occurrence of the stroke in the city of Fortaleza with other cities, based on national studies. A transversal study developed with 180 patients who were diagnosed with stroke in nine different public institutions within the period from October 2007 to April 2008. For data collection, a questionnaire was applied by interviewing the patient and/or their companions. The following tests were used for the comparative analysis of epidemiological data: The Chi-Square Test for the adherence and the T-Test for the mean. The patients with stroke evaluated in Fortaleza were younger and had higher rates of hypertension than in the national profile, however, fewer were smokers or consumers of alcohol. It is necessary to increase knowledge about the health of the Brazilian population by region, since there are specific influential factors in the occurrence of stroke.

Descriptors: Nursing; Epidemiology; Stroke.

\footnotetext{
${ }^{1}$ Work developed in the Joint Project Cuidado em Saúde Cardiovascular. Supported by CNPq, Process \# 306149/2006-0.

${ }^{2}$ RN, Doctoral Student, Universidade Federal do Ceará, CE, Brazil. Professor, Faculdade Católica Rainha do Sertão, CE, Brazil. E-mail: tahissa@ig.com.br.

${ }^{3}$ RN, Doctoral Student, Universidade Federal do Ceará, CE, Brazil. E-mail: rafaellapessoa@hotmail.com.

${ }^{4}$ RN, Ph.D. in Nursing, Associate Professor II, Universidade Federal do Ceará, CE, Brazil. E-mail:thelmaaraujo2003@yahoo.com.br. ${ }^{5}$ RN, Ph.D. in Nursing, Adjunct Professor IV, Universidade Federal do Ceará, CE, Brazil. E-mail: marcos@ufc.br.
}

Corresponding Author:

Tahissa Frota Cavalcante

Rua Capitão Justino Ferreira Ramos, no 230, casa 02

Bairro Lagoa Redonda

CEP: 60833-025 Fortaleza, CE, Brasil

E-mail: tahissa@ig.com.br 


\section{Fatores demográficos e indicadores de risco de acidente vascular encefálico: comparação entre moradores do município de Fortaleza e o perfil nacional}

O objetivo deste estudo foi comparar fatores demográficos e indicadores de risco para o aparecimento de acidente vascular encefálico (AVE), entre o município de Fortaleza e outros municípios, com base em estudos nacionais. É um estudo transversal, desenvolvido com 180 pacientes que apresentaram o diagnóstico de AVE, no período de outubro de 2007 a abril de 2008. Referidos pacientes foram captados em nove instituições públicas. Para a coleta de dados, aplicou-se formulário, por meio de entrevista, ao paciente e/ou acompanhante. Para análise comparativa dos dados epidemiológicos, foram utilizados os seguintes testes estatísticos: teste qui-quadrado para aderência e teste t para média. Os portadores de AVE avaliados em Fortaleza são mais jovens e apresentaram maiores índices de hipertensão arterial. Em contrapartida, são menos etilistas e tabagistas. É necessário ampliar o conhecimento sobre a saúde da população brasileira, estratificada por regiões, já que existem fatores influenciadores específicos para a ocorrência do acidente vascular encefálico.

Descritores: Enfermagem; Epidemiologia; Acidente Cerebral Vascular.

\section{Factores demográficos e indicadores de riesgo de accidente vascular encefálico: comparación entre residentes del municipio de Fortaleza con el perfil nacional}

El objetivo de este estudio fue comparar factores demográficos e indicadores de riesgo para el aparecimiento del accidente vascular encefálico (AVE) entre el municipio de Fortaleza y otros municipios, con base en estudios nacionales. Estudio transversal desarrollado con 180 pacientes que presentaron el diagnóstico de AVE, en el período de octubre de 2007 a abril de 2008. Los pacientes fueron captados en nueve instituciones públicas. Para la recolección de datos, se aplicó un formulario por medio de entrevista al paciente y/o acompañante. Para análisis comparativo de los datos epidemiológicos fueron utilizados las siguientes pruebas estadísticas: Chi-cuadrado para adherencia y prueba t para promedio. Los portadores de AVE evaluados en Fortaleza son más jóvenes y presentaron mayores índices de hipertensión arterial. En contrapartida, son menos alcohólicos y tabaquistas. Concluimos que es necesario ampliar el conocimiento sobre la salud de la población brasileña estratificada por regiones, ya que existen factores específicos que influyen en la ocurrencia del accidente vascular encefálico.

Descriptores: Enfermería; Epidemiología; Accidente Cerebrovascular.

\section{Introduction}

Health in Brazil has an epidemiological profile characterized by heterogeneity. However, improvements have been observed within the country's health situation which favor the aging population such as, increase in life expectancy at birth, reduced maternal-infant mortality, increased survival, control and eradication of some diseases $^{(1)}$.
This situation leads to an increase in chronic diseases, particularly of the cardiovascular system, which attain relevance in the morbimortality data of the country ${ }^{(1-2)}$. Among the cardiovascular diseases, stroke is a pathology with profound implications for public health, as it is currently the second leading cause of death in Brazil and the first of disability in adults ${ }^{(2-3)}$. 
In 2003, in the Northeast of Brazil, the mortality rate from stroke was 54.6/100,000 inhabitants ${ }^{(2)}$. In Ceará, in 2004 , this rate was $44.8 / 100,000$ inhabitants $^{(4)}$. In Fortaleza, in the same year, diseases of the circulatory system accounted for $25.4 \%$ of all hospitalizations, in the National Health System, of individuals over 65 years $^{(5)}$.

This aging of the population, associated with increased risk factors for cerebrovascular disease such as arterial hypertension, diabetes mellitus, smoking, alcohol consumption, dyslipidemia and obesity, explains, in part, the high incidence of stroke(3).

The high trend of hospitalizations for stroke generates a significant increase in costs of hospital admissions, which require specialized and complex treatments. The serious health and social consequences, such as the physical, emotional and functional sequelae also need to be considered ${ }^{(1)}$. Furthermore, from the hospital discharge, a partnership between the hospital and home becomes vital, in order to ensure continuity of care, reduce readmissions and, therefore, reduce the cost of hospitalization for stroke ${ }^{(6)}$.

These sequelae involve some degree of dependency, especially in the first year after the occurrence of the stroke, with approximately $30 \%$ to $40 \%$ of survivors unable to return to work, making them dependent on retirement and Social Security benefits ${ }^{(1,7-8)}$.

A study on the epidemiology of cardiovascular diseases in Brazil has shown that inter and intra-regional differences exist and that those are not being studied(2). Another study shows that mortality from stroke is higher in the poorest regions of Brazil, such as the Northeast, and, in many cases, this high morbimortality is attributed to unfavorable social factors ${ }^{(9)}$.

The aim of this study was to compare the demographic factors and risk indicators for the onset of stroke between the city of Fortaleza and other cities, based on national studies.

This work is of importance in view of the need for studies that address the recognition and early detection of probable triggering factors of cerebrovascular disease in the population. It should also be emphasized that there is a shortage of nursing research focused on this theme, since a large part refers only to aspects of the caregiver and patient in the rehabilitation phase ${ }^{(10-12)}$.

\section{Materials and Methods}

This was a cross-sectional study carried out with 180 patients who had a clinical diagnosis of stroke.
The inclusion criteria chosen were: to have the medical diagnosis of stroke, age over 18 years, no previous history of stroke. Sampled by convenience, consecutively from October 2007 to April 2008, patients were selected from nine public institutions.

These were: the emergency unit of a tertiary level, public, general hospital and eight institutions of the Cearense Benevolent Association of Rehabilitation (ABCR) located in the city of Fortaleza, Ceará, Brazil. While the hospital was selected to be a reference for treating patients with stroke in the Northeast region, the $A B C R$ were selected for the care of patients suffering from motor disability due to sickness or injury and in need of rehabilitation. Prominent among the clientele were people suffering from sequelae originating from stroke.

For the data collection, a questionnaire was applied by interviewing the patient. However, for patients unable to communicate verbally, the interview data were obtained from their companions. The questionnaire contained topics on socioeconomic data, such as sex, age, marital status, income and schooling and cerebrovascular risk factors: arterial hypertension, diabetes mellitus, smoking and alcohol consumption.

For analysis of the variables, marital status was considered as the patient living with or without a partner at the time. For schooling, the criteria were the years of study of each participant. All risk indicators were recognized as present when there was explicit reference by the respondent and/or companion at the time of data collection.

With the exception of the variables sex, marital status and alcohol consumption, the total number of respondents was less than 180, because in these cases there was no response from the participant or companion. The data were compiled as spreadsheets using Excel ${ }^{\circledR}$ software and statistical analysis was carried out using SPSS ${ }^{\circledR}$ version 16.0.

For comparative analysis of epidemiological data the following statistical tests were used: KolmogorovSmirnov test to verify the adherence of numeric variables to the normal distribution, the Chi-Square test for the adequacy of adjustment and test for the mean. The significance level adopted for the study was 0.05 .

The reference data from national studies ${ }^{(1,3,13)}$ used for comparison with data collected in this research for each variable were: sex (ratio male/female - 1.2:1)(1,3), age $(\text { mean }=65.2 \text { years })^{(13)}$, arterial hypertension $(50.0 \%)^{(3)}$, diabetes mellitus $(20.0 \%)^{(13)}$, smoking $(50.0 \%)^{(13)}$ and 
alcohol consumption (35.1\%) ${ }^{(13)}$. Regarding the variables schooling, income and marital status, no national studies were found that addressed the prevalence of these. Thus, the analysis of these data was merely descriptive.

In compliance with the ethical recommendations, the study was approved by all directors of the participating institutions and was then sent to the Research Ethics Committee. Thus, the recommendations of Resolution 196/96, concerning research developed with human beings, were fulfilled and approval was obtained under the protocol numbers 180906/07 and $211 / 7$.
In addition, all participants were informed about the established goals and signed the free prior informed consent form. Acceptance and signature of the terms of consent of patients with substantially decreased capacity for discernment were given by legal representatives and/ or family members of those subjects, without suspension of the rights of information of the individual, within the limits of their capacity.

\section{Results}

The sociodemographic data of patients with stroke is presented in Table 1.

Table 1 - Distribution of patients with stroke by sociodemographic data. Fortaleza, 2008

\begin{tabular}{|c|c|c|c|c|c|c|c|}
\hline Variables & $\mathbf{N}^{\circ}$ & $\%$ & $p$ value & & & & \\
\hline Sex & & & $0.134^{*}$ & & & & \\
\hline Male & 88 & 48.9 & & & & & \\
\hline Female & 92 & 51.1 & & & & & \\
\hline \multicolumn{8}{|l|}{ Marital status } \\
\hline With partner & 97 & 53.9 & & & & & \\
\hline Without partner & 83 & 46.1 & & & & & \\
\hline Variables & Mean & $\mathbf{S D}^{+}$ & $\mathbf{P}^{\prime} 5^{\ddagger}$ & P75 & Median & K-S (p value) ${ }^{\prime \prime}$ & $p$ value \\
\hline Age (years) & 62.3 & 13.6 & 53.0 & 72.0 & 62.5 & 0.85 & $0.005^{\natural}$ \\
\hline Schooling (years) & 4.3 & 4.4 & 0 & 7.0 & 3.0 & 0.00 & - \\
\hline Income $\mathrm{R} \$ /$ month & 513.4 & 460.4 & 415.0 & 415.0 & 415.0 & 0.00 & - \\
\hline
\end{tabular}

* Chi-Square test for the adequacy of the adjustment. ${ }^{\dagger} \mathrm{SD}-$ Standard Deviation. ${ }^{*}$ P25 - 25 th percentile. ${ }^{\S}$ P75 - 75 th percentile. ${ }^{I I}$ K-S - KolmogorovSmirnov test. "T Test.

When analyzing sociodemographic variables the following were found: predominantly female $(51.1 \%)$, marital status with partner (53.9\%), mean age $(62.3$ years), median schooling (three years of study) and median income ( $\mathrm{R} \$ 415.00 /$ month).

The variables schooling and income presented skewed distributions $(p<0.05)$, with greater concentration on lower values, indicating low income and education. The mean age of the sample was statistically lower than that observed in a national study (mean 65.2 years) $(p=0.005)$.

Regarding risk indicators for the occurrence of cerebrovascular diseases, $77.2 \%$ of patients with stroke were hypertensive, $23.5 \%$ diabetic, $31.9 \%$ smokers and $21.2 \%$ consumed alcohol. The proportion of risk indicators for cerebrovascular diseases in Fortaleza was statistically different from the values found in national studies for arterial hypertension, smoking and alcohol consumption.

In Fortaleza, patients with stroke had a higher frequency of arterial hypertension ( $p=0.000)$ and lower frequency of smoking $(p=0.000)$ and alcohol consumption ( $p=0.000)$.

Table 2 - Distribution of risk indicators for cerebrovascular diseases present in patients with stroke. Fortaleza, 2008

\begin{tabular}{lcccc}
\hline $\begin{array}{c}\text { Risk indicators for } \\
\text { cerebrovascular diseases }\end{array}$ & $\mathbf{N}^{\circ}$ & $\%$ & Total & $\mathbf{p}^{*}$ value \\
\hline $\begin{array}{l}\text { Arterial hypertension } \\
\quad \text { Present }\end{array}$ & 135 & 77.2 & & 0.000 \\
$\quad$ Absent & 40 & 22.8 & & \\
Diabetes mellitus & & & 175 & 0.257 \\
$\quad$ Present & 41 & 23.5 & & \\
$\quad$ Absent & 134 & 76.5 & & \\
Smoking & & & 179 & 0.000 \\
$\quad$ Present & 57 & 31.9 & & \\
Absent & 122 & 68.1 & & \\
Alcohol consumption & & & & \\
Present & 38 & 21.2 & 180 & 0.000 \\
Absent & 142 & 78.8 & & \\
\hline
\end{tabular}

* Chi-Square test for adequacy of the adjustment. 


\section{Discussion}

In this study, women were prevalent. Contrary to these obtained findings, several national surveys found a slightly higher prevalence of stroke in the male population ${ }^{(1,13-16)}$.

Despite not finding a statistical association regarding sex with another national study, it is believed that this slight predominance of females can be attributed to age because the survival of women until older ages is higher than men, and thus there is an apparent excess of stroke in the female population (3).

As shown by some studies that relate the mortality rates for stroke with gender, this mortality is higher among women than among men ${ }^{(9,17)}$.

In this study, the mean age of subjects was 62.3 years $(S D=13.6)$. Although stroke is a cerebrovascular disease which can happen at any age, its incidence increases with advancing age, and approximately doubles with each decade of life ${ }^{(3)}$. According to some authors, the incidence of stroke peaks between the seventh and eighth decades of life, when the cardiovascular and metabolic alterations combine, due to the aging process $^{(18)}$.

Other studies on this subject have confirmed this information. For example, work carried out in Spain with patients with stroke found an average age of 75.7 years $(S D=1.9)^{(17)}$ and a multicenter study conducted in seven European countries found that the average age of patients was 70.9 years $(S D=12.4)^{(14)}$.

This slight discrepancy in the mean age is explained by patients being evaluated at the first episode of the disease. However, when compared with another study, which also considered the first episode of stroke, the patients in this study were younger. Another study states that there are a considerable number of people below the age of 50 affected by stroke ${ }^{(19)}$.

The fact that this disease occurs in younger people is justified in part by the high prevalence of arterial hypertension (77.2\%) found in the evaluated population. Furthermore, this prevalence was higher when compared to another study conducted in the Southeast region of Brazil ( $p=0.000)$.

A study which estimated the prevalence of arterial hypertension in Brazil found that the Northeast region has the highest prevalence ( $7.2 \%$ to $40.3 \%$ ), followed by the Southeast region (5.04\% to $37.9 \%$ ), the South $(1.28 \%$ to $27.1 \%)$ and the Midwest $(6.3 \%$ to $16.7 \%)^{(20)}$.
The inter-regional disparities probably reflect a difference in the quantity of risk factors, which include lifestyle (physical activity level, smoking and alcohol consumption), as well as access to diagnostic and therapeutic resources ${ }^{(2)}$. This is because the Northeast region is one of the poorest in Brazil and has limited access to primary, secondary and tertiary health services.

The high prevalence and clustering of risk factors for cerebrovascular disease among patients with hypertension reinforces the need not only to improve the diagnosis and treatment of arterial hypertension, but also to approach integrally the risk profile of this population. Among the risk factors addressed by the study, smoking was found in $31.9 \%$ of patients and consumption of alcohol in $21.2 \%$. In this study fewer patients smoked and consumed alcohol compared to other patients evaluated in a study conducted in the Southeast.

It is important to consider that other factors such as schooling and income may interfere in the occurrence of cerebral vascular accident. However, it was not possible to compare these data because of the lack of national studies that addressed such aspects.

The increased incidence of stroke is also related to the decrease in socioeconomic level. Regarding causes for this situation a study shows a higher frequency of risk factors for cerebrovascular disease, unfavorable psychosocial factors and limited access to health services $^{(21)}$. Moreover, a longitudinal study with 47,942 participants identified a strong relationship between the incidence of stroke and years of schooling, showing that the incidence was two times higher among people with a low education(22).

\section{Conclusion}

The patients with stroke evaluated in Fortaleza were younger and had higher rates of arterial hypertension. In contrast, there were fewer alcohol consumers and smokers. However, there was a limitation in this study, namely the inability to compare other factors such as schooling and socioeconomic status.

There is a need to expand our knowledge by means of further scientific studies on the health of the Brazilian population as a whole and stratified by region, considering that age, risk factors and economic and social factors may influence the incidence of stroke differently in different regions of Brazil. 


\section{References}

1. Falcão IV, Carvalho EMF, Berreto KML, Lessa FJD, Leite VMM. Acidente vascular cerebral precoce: implicações para adultos em idade produtiva atendidos pelo Sistema Único de Saúde. Rev Bras Saúde Matern Inf. 2004; 4(1):95-102.

2. Curioni $C$, Cunha $C B$, Veras RP, André $C$. The decline in mortality from circulatory diseases in Brazil. Pan Am J Public Health. 2009; 25(1):9-15.

3. André C. AVC agudo. In: André C. Manual de AVC. Rio de Janeiro: Revinter; 2006. p. 37-51.

4. Secretaria de Saúde do Estado do Ceará (BR). Indicadores e dados básicos para a saúde no Ceará 2004. Fortaleza; 2005.

5. Ministério da Saúde (BR). Sistema de Informações Hospitalares. Indicadores municipais de saúde: morbidade hospitalar no município de Fortaleza-CE. Brasília; 2004. [acesso em: 20 out 2006]. Disponível em: http://www..saude.gov.br

6. Mesquita SRAM, Anselmi ML, Santos CB, Hayashida M. Programa Interdisciplinar de internação domiciliar de MaríliaSP: custos de recursos materiais consumidos. Rev. Latino-Am. Enfermagem. 2005; 13(4):555-61.

7.Moreira RP. Acidente vascular encefálico - análise dos diagnósticos de enfermagem da classe Atividade/Exercício. [dissertação]. Fortaleza: Universidade Federal do Ceará; 2008.

8. Perlini NMOG, Faro ACM. Cuidar de pessoa incapacitada por acidente vascular cerebral no domicílio: o fazer do cuidador familiar. Rev Esc Enferm USP. 2005;39(2):154-63.

9. Lotufo PA. Stroke in Brazil: a neglected disease. São Paulo Med J. 2005; 123(1):3-4.

10. Bocchi SCM, Angelo M. Entre a liberdade e a reclusão: o apoio social como componente da qualidade de vida do binômio cuidador familiar-pessoa dependente. Rev. Latino-Am. Enfermagem. 2008;16(1):15-23.

11. Marques S, Rodrigues RAP, Kusumota L. O idoso após acidente vascular cerebral: alterações no relacionamento familiar. Rev. Latino-Am. Enfermagem. 2006;14(3):364-371.

12. Bocchi SCM. Vivenciando a sobrecarga ao vir-a-ser um cuidador familiar de pessoa com acidente vascular cerebral (AVC): uma análise do conhecimento. Rev. Latino-Am. Enfermagem. 2004;12(1):115-21.
13. Pires SL, Gagliardi RJ, Gorzoni ML. Estudo das freqüências dos principais fatores de risco para acidente vascular cerebral isquêmico em idosos. Arq Neuropsiquiatr. 2004;62(3-B):844- 51.

14. Di Carlo A, Lamassa M, Baldereschi M, Pracucci G, Consoli $D$, Wolfe $C D A$, et al. Risk factors and outcome of subtypes of ischemic stroke. Data from a multicenter multinational hospitalbased registry. The European Community Stroke Project. J Neurol Sci. 2006; 244: 143-50.

15. Medrano Albero MJ, Boix Martínez R, Cerrato Crespán E, Ramírez Santa-Pau M. Incidencia e prevalencia de cardiopatia isquêmica y enfermedad cerebrovascular en Espana: revisión sistemática de la literatura. Rev Esp Salud Pública. 2006; 80(1):5-15.

16. Moreno VP, García Raso A, García Bueno MJ, Sánchez Sánchez, A, Meseguer E, Mata $R$ et al. Factores de riesgo vascular en pacientes com ictus isquémico. Distribución según edad, sexo y subtipo de ictus. Rev Neurol. 2008; 46(10):593-8.

17. Sanclemente Ansó C, Alonso Valdés F, Rovira Pujol E, Vigil Martín D, Vilaró Pujals J. Accidentes vasculares cerebrales en la comarca de Osona. Factores de riesgo cardiovascular. An Med Int. (Madrid) 2004; 21(4):161-5.

18. Zétola VHF, Nóvak EM, Camargo CHF, Carraro Júnior H, Coral P, Muzzio JÁ, et al. Acidente vascular cerebral em pacientes jovens: análise de 164 casos. Arq Neuropsiquiatr. 2001; 59(3B): 740-5.

19. Gomes SR, Senna M. Cliente com acidente vascular cerebral e as interfaces da assistência de enfermagem para reabilitação. Online Braz J Nurs. 2008; [Internet]. 7(2). [acesso em: 14 setembro 2008]. Disponível em: http://www.uff.br/objnursing/ index.php/nursing/article/view/j.1676-4285.2008.1420/386.

20. Passos VMA, Assis TD, Barreto SM. Hipertensão arterial no Brasil: estimativa de prevalência a partir de estudos de base populacional. Epidemiol Serv Saúde. 2006;15(1):35-45.

21. Kurth T, Berger K. The socioeconomic stroke puzzle. Stroke. 2007; 38:4-5.

22. Kuper H, Adami HO, Theorell T, Weiderpass E. The socioeconomic gradient in the incidence of stroke - a prospective study in middleaged women in Sweden. Stroke. 2007; 38:27-33.

Received: Aug. $20^{\text {th }} 2009$

Accepted: Apr. $13^{\text {th }} 2010$ 